\author{
Birgit Mersmann \\ University of Cologne \\ Kunsthistorisches Institut \\ Abteilung Allgemeine Kunstgeschichte \\ Albertus-Magnus-Platz \\ 50923 Köln \\ b.mersmann@uni-koeln.de
}

\title{
PERFORMING THE CITY'S URBAN IMAGINARY - THE NEW TAIPEI CITY MUSEUM OF ART
}

\begin{abstract}
Aspiring global cities, such as Taipei City in Taiwan, seek to accumulate cultural capital. For future-oriented local and global self-representation, they design cutting-edge contemporary museums. This paper analyzes the "urban imaginary" as constructed by new urban museumscapes. Choosing a case-study approach, it explores the embedding of a vanguard art museum project in Taiwan - the New Taipei City Museum of Art in Taipei - into long-term urban planning strategies. In order to understand the purpose and process of how the new museum of contemporary art is devised as a public space of cultural self-representation and urban identity building, the study monitors the complete design process from the city government's urban and institutional planning strategy to the architectural design. Evidence shows that the pathways of urban place-making for art and through art and design in Taipei are strongly determined by the historical role and current geopolitical repositioning of the city.
\end{abstract}

\section{Keywords:}

Taipei, urban museumscape, urban planning, urban identity, contemporary architecture

The capital link between cultural place-making and urban development is especially pronounced in world cities whose geopolitical influence is on the rise. Aspiring global cities, such as Taipei City in Taiwan, seek to accumulate cultural capital by a three-fold strategy ${ }^{1}$ : a people-oriented strategy, a product-oriented strategy, and a place-making strategy. The place-making strategy draws upon the creation of infrastructure and property development. Among it,

\footnotetext{
${ }^{1}$ Won-Bae Kim, "Strategic Approaches for Sustainable Cultural Development in Asian Cities," paper presented at the International Conference on the Culture and Economy of Cities, jointly organized by the Korea Research Institute for Human Settlements and the University of New South Wales, Seoul, Korea, 11-12 October 2001.
} 
the design of new museums is considered part of the larger institutional place making strategy. ${ }^{2}$ Exploring the urban-culture connection for Asian cities on the basis of a comparative city study, Lily Kong could evidence how the efforts of city governments "to develop cultural icons" are part "of the strategy to help their cities gain global city status, and in the process, constructing shared national and city identities. ${ }^{3}$ The accumulation of cultural capital is strategically pursued by the municipalities of global cities in order to secure long-term success in global governance, politics, and business. It manifests itself through the creation of new cultural urban spaces, be it single cultural institutions such as museums, grand theatres, concert halls, libraries, or even entire cultural districts with monumental structures, such as the West Kowloon Cultural District in Hong Kong.

The Asian endeavor for local and global self-representation through contemporary art museums demonstrates a new ongoing trend. The planning of new museums, in particular of the MoCA type with its distinct incorporation of advancement and forwardlookingness, has become an integral part of urban planning strategies and the construction of city identities. Shaped by cutting-edge iconic architecture, these new museums aspire to be vanguard futurist image-makers, breaking ground for the urban, political, social, and cultural redesign of the museum as well as for the urban revitalization of the city in the twenty-first century.

For studying the tight urban link between museum-, city-, identity- and image-building in globally active cities in Asia, one case study was selected: the newly planned and designed New Taipei City Museum of Art in New Taipei City, Taiwan, whose opening is scheduled for 2019. My study on New Taipei City's "urban imaginary" as produced by the creative imagination of the new contemporary art museum follows a regional urban approach. It seeks to find out how Taipei City reimagines and reinvents itself as future-oriented world city of the $21^{\text {st }}$ century through the innovative design of urban museumscapes. The notion of the museumscape refers to both the new landscape of museums in global flux and the urban rooting of museums. ${ }^{4}$ In order to expose how the

\footnotetext{
${ }^{2}$ Cp. Lily Kong's comment on place-making strategies in global cities: "The global city must at the very least support cultural institutions such as museums, theatres and libraries, which should in turn sustain global flows by attracting capital investment and drawing tourists through contributing to an urban image befitting a global city, and supporting a culturally enriched lifestyle." Lily Kong, "Cultural Icons and Urban Development in Asia: Economic Imperative, National Identity, and Global City Status," Political Geography 26 (2007): 384.

3 Ibidem: 383.

${ }^{4}$ The term "museumscape" has been modeled after the five scapes described by Appadurai as decisive factors of the global cultural economy. Arjun Appadurai, "Disjuncture and Difference in the Global Cultural Economy," Public Culture 2 (1990): 1-24. Although it is often used by museums and for museum projects, it has not yet been theorized in museums studies.
} 
museum building is largely embedded into urban planning strategies and city development, the analysis monitors the complete design process from the city government's urban and institutional planning strategies over architectural design to the museum's mission statement. The investigation is concerned with museum design concepts (the software), but not with the construction of the museum (the hardware). It expresses particular interest in the concatenation of museum curating and city curating. For this reason, it will focus on the "idea" competition for the New Taipei City Museum of Art that was conducted in 2011, and not cover the professional competition whose final award winning design of Kris Yao, a Taiwanese architect, was announced in 2015 (see fig. 1).

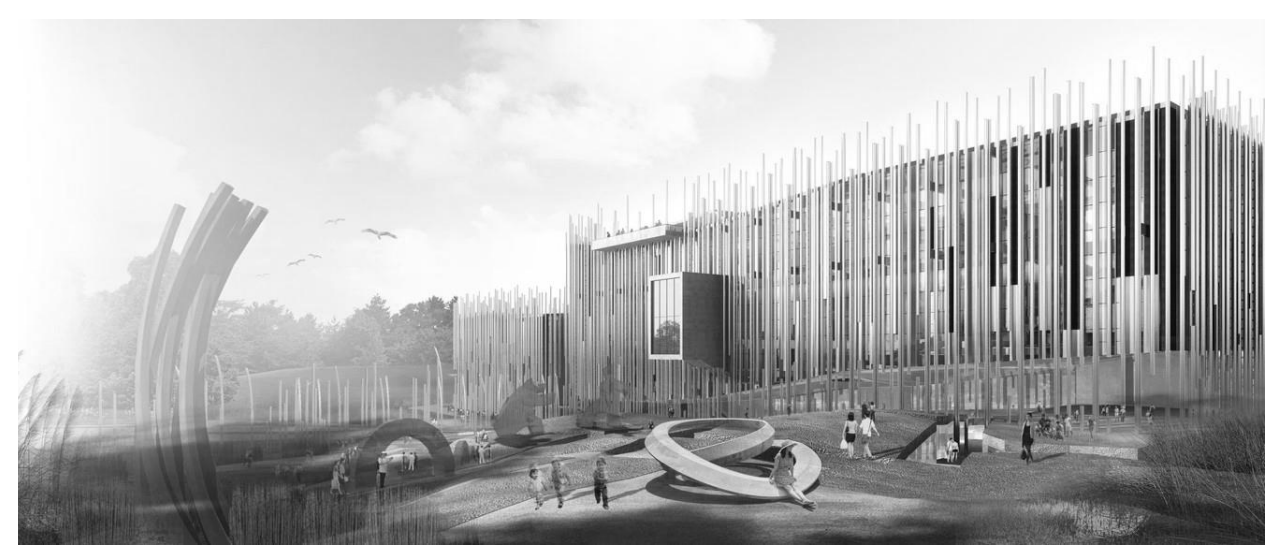

Fig. 1. Kris Yao, Design of New Taipei City Museum of Art, 2015. Source: Kris Yao.

\section{BUILDING A REGIONAL CITY WITH GLOBAL VIBES: THE DEVELOPMENT OF NEW TAIPEI CITY}

The deliberately regional location of the New Taipei City Museum of Art in the New Taipei county that surrounds Taiwan's capital gives it a different flavor and feature. Not being placed in the heart of the capital, but in the larger Taipei metropolitan area is a strategic planning move for building a regional cultural city that requires particular investigation. In order to understand the urban outmigration of the museum, its "expulsion from the capital," one has to take a closer look at the regional-political, economic and historical role of the New Taipei City County.

With a population of over 3.9 million and an area of 2052 square kilometers, New Taipei City is the biggest county in Taiwan. It is a major hub for business industries, "second to Taipei City, with over 250.000 privately owned companies and 20.000 factories, which sums up to a total capital of NTD (New Taiwan 
Dollar) 1.8 trillion." ${ }^{5}$ Beside high technology, service, and tourism, the cultural and creative industries form the major industries in New Taipei City. The enormous economic success of the Taipei County was one of the main reasons why, in January 2011, the county - previously under the jurisdiction of Taipei City - was transformed into an autonomous municipality represented by a Mayor. The renaming of the Taipei County into "New Taipei City" clearly marked the upgrading from county to city status, with some irritating effects, since a regional unit is administratively and symbolically metropolized. The newly gained autonomous city status allowed for increased budget flow and innovative flagship projects. The New Taipei City Museum of Art project counts among them, made possible by the conferment of municipal rights. Although competition is spurred by the city duality of (Old) Taipei City and New Taipei City, the city upgrading of the former county seems to anticipate a future reunification of the two neighboring cities into Grand Taipei. The area of New Taipei City could be easily merged with (Old) Taipei City, thus forming a super-large city region of increasingly regional and global impact. Seeing that Taipei City represents one of the rising city powers in Asia, it makes strategic sense to bundle city synergies and build a regional city hub in the Northern Taiwan area, the historical spearhead of the tiger economy. The Greater Taipei Plan, devised in 2005 by the Construction and Planning Bureau of Ministry of the Interior, already reflected the government's special interest in the Northern Taiwan Regional Development. It suggested a metropolitan conurbation connecting Taipei City, Taipei County (now New Taipei City) and Taoyuan County extending to Hsinchu.

The new city denomination of Taipei county has fueled the search for a new regional city identity and history. As the card of national identity cannot be played due to the conflict with China, forgotten, overlooked or oppressed local identities are revived in order to give New Taipei City a cultural face. On the official website of the New Taipei City Government, New Taipei City is advertised as "a city filled with cultural and creative industry [...] like pottery industry in Yingge, Liuli ${ }^{6}$ industry in Tamsui, drums in Xinzhuang, dye in Sanxia, noble metal processing in Ruifang, and sky lantern in Pingxi." ${ }^{\prime 7}$ According to this description, the creative industries are built by traditional arts and crafts, and not by contemporary art, design, and new media. For preserving the unique tradition of ancient arts and crafts production, different types of museums (by now numbering 32) and galleries have been established in the New Taipei City area. The city government of New Taipei City has realized the

\footnotetext{
5 "Introduction" on New Taipei City Government official website, accessed February 17, 2017, http://foreigner.ntpc.gov.tw/content/?parent_id=10058.

${ }^{6}$ Liuli is glass created by means of the pâte-de-verre technique.

7 "Introduction," New Taipei City Government.
} 
cultural and historical significance of this heritage and formed a Treasure Group, magically called "The Seven Beautiful Families," under the responsibility of the Bureau of Cultural Affairs in order to "welcome a new museum era" that will transform New Taipei City into a fascinating museum (city). Flagship projects of the emerging museumscape are the New Taipei City Ceramics Museum in Yingge, the Lei Meishu Museum (a memorial gallery commemorating the merits of the artist and architect Lei Meishu), and the New Taipei City Hakka Museum, opened with the aim to conserve and research the Hakka culture and promote the cultural integration of different ethnic groups, including the indigenous people of Taiwan. Within this cluster of museums, one important museum type was a missing link: a museum of contemporary art by which the newness of New Taipei City, its aspiration to become the new regional capital of Taiwan and a top-city tourist destination on the cultural world map, could be adequately represented.

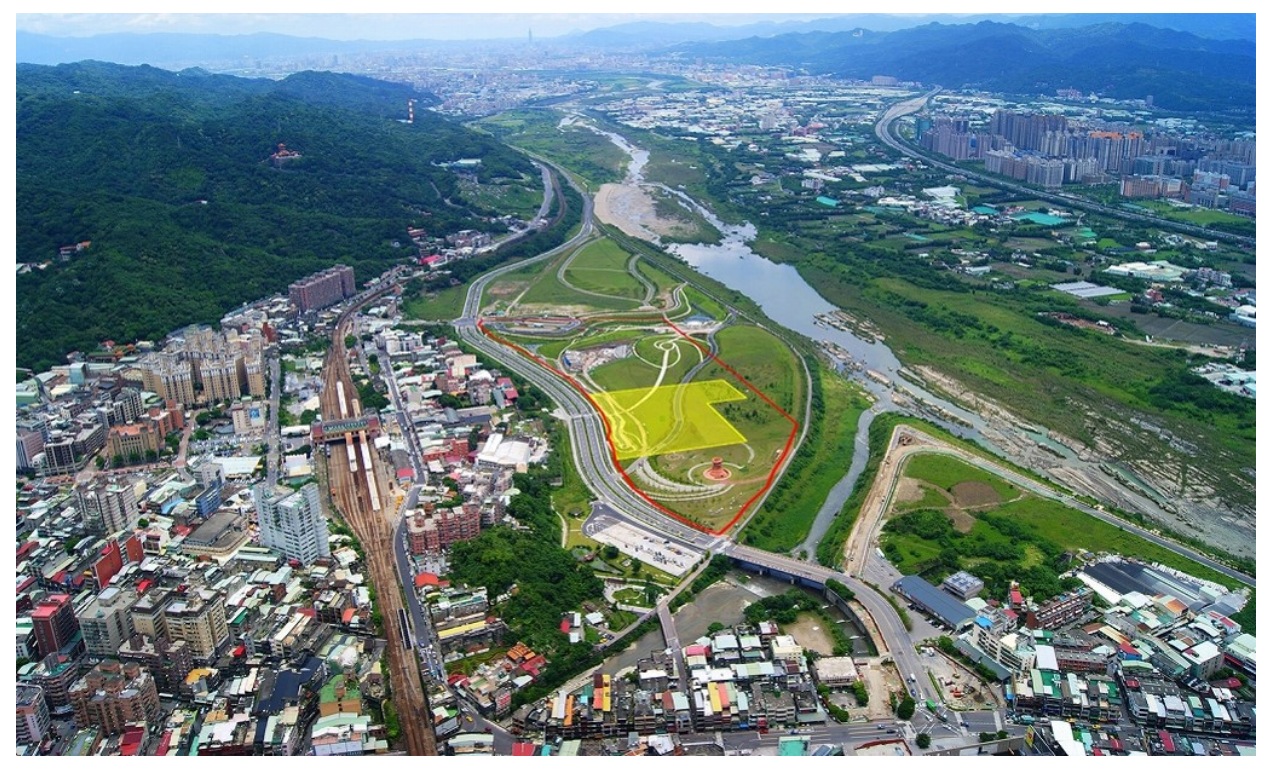

Fig. 2. Site for the construction of the New Taipei City Museum of Art. Source: Atelier Boronski.

A spectacular site in New Taipei City at the crossings of the Yingge and Dahan rivers, in close neighborhood to the newly built Ceramics Museum in Yingge District was selected for the construction of the newly designed museum of contemporary art (see fig. 2). ${ }^{8}$

${ }^{8}$ The Compilation and Promotion of the Greater Danshui Artist Map is the first-stage plan from the "New Taipei City Artist Map Project" issued by the Culture Affairs Bureau of New Taipei City. The goal of this project, named "One Year, One Village," is to conduct field survey, in-depth 
SUBMETROPOLITAN GLOBALISM: CONCEPTUAL URBAN DESIGNS FOR THE NEW TAIPEI CITY MUSEUM OF ART

The "newness" of the conceptual urban design builds the focus of the following case study analysis of the New Taipei City Museum of Art. ${ }^{9}$ Since many spectacular design proposals have been submitted for the International Design Competition, the conceptual analysis concentrates on the museum designs of the three prize winners: the proposals by first prize winner Jean-Loup Baldacci \& Atelier Boronski (France/New Zealand with a practice in Japan), second prize winner Kengo Kuma \& Associates (Japan), and third prize winner Frederic Soriano Pelaez (Spain). The "New Taipei City Museum of Art Conceptual Design International Competition" was announced in 2011 by the Cultural Affairs Department of the New Taipei City Government. The objective of the competition was "to build a world-class museum of art [...] creative and visionary schemes are sought in order to give New Taipei City Museum of Art a fresh look and versatile art exhibition space. The design teams from all over the world are invited to challenge the imagination, pursue new possibilities for modern art museums and help New Taipei City create an artistic icon for the new century." 10 This open call for imagining an innovative, forward-looking and iconic world-class museum of art has become a kind of stereotype which, like a litany, seems to ritualize the cultural design process of global cities or cityregions. The newness carried in the name of the New Taipei City Museum of Art was set out by the city government as a guiding principle for the conceptual design plan. The expectation associated with the competition was that a new form of art museum, a new type of exhibition space, and a new design for the new century should be invented by the nouveau design for the New Taipei City Museum of Art. The articulated emphasis on innovative and Avant-gardistic design ideas was one of the reasons why, besides any licensed architect of Taiwan or a foreign country, design-related companies as well as any student recommended by a design-related department of the university of Taiwan (R.O.C) or foreign country, alone or in teams, were eligible to submit a design proposal. Numerous submitted proposals have pushed the museum-architectural design of newness to the very limits, with highly futuristic museum visions of

interviews, artwork digitization and promotional events on artists and art villages within New Taipei City.

${ }^{9}$ On the factor of "newness" and innovation as core criteria for the creation of contemporary museums, cp. Kylie Message 2006.

10 "New Taipei City Museum of Art Conceptual Design International Competition," description under Akichiatlas.com. website, accessed February 18, 2017, http://akichiatlas.com/en/archives/ new_taipei_museum.php. 
extraterrestrial space dimensions. ${ }^{11}$ While visualizing and modeling high-flying museum dreams, some architects have blanked out the local reality and culture. The design by the London-based architecture practice "meterbuilt," for instance, was disqualified by the Taiwanese blogger community for a major linguistic faux-pas, as it showed a Chinese writing on the museum's entry side in simplified Chinese instead of traditional Mandarin characters which are used in Taiwan.

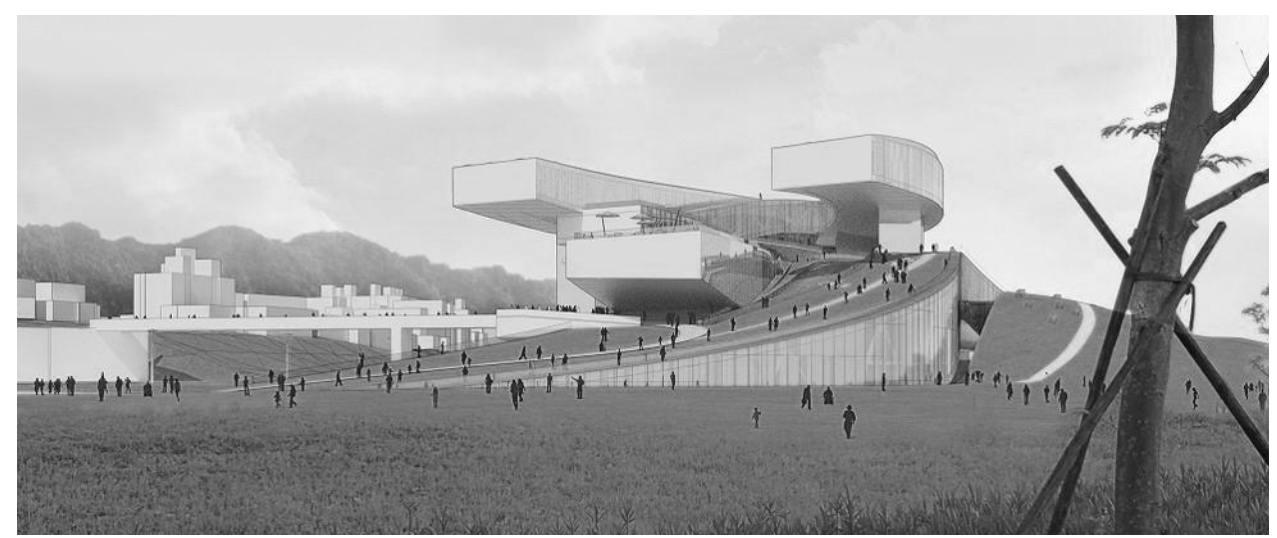

Fig. 3. Museum Design of Atelier Boronski \& Jean-Loup Baldacci for New Taipei City Museum of Art, International Design Competition 2011. Source: Atelier Boronski.

How did the three prize winners meet the challenge of inventing a new conceptual urban design for the New Taipei City Museum of Art? The first prize winning proposal by the Atelier Boronski (an architect from New Zealand with a practice in Japan) in cooperation with Jean-Loup Baldacci (a joint architect from France) aimed at creating a field of dreams and a building for the people (see: fig. 3). Public participation opportunities and open accessibility to the new museum as dream site form the core of the design. The implementation of these key features is attained by merging park and street on exactly the architectural site where the museum building is positioned. The building is "completely accessible for people to walk and even ride bicycles all over. The public can easily 'take possession' of this building, even just to come and sit on the grass and enjoy the view as they picnic on these huge pieces of 'ground' floating in

\footnotetext{
${ }^{11}$ A blog comment on one of the proposed museum designs, signed with "disgruntled" and dated September 11, 2011, reflects the critical stance on this architectural race for hypermodern and cool newness: "Is this the state of architecture now? Everything that is shown has to have a sense of extravagance, an obligation to wow, excite with theatrics? We have prostituted ourselves, our dignity and responsibility to make sensible spaces." Lauren Grieco, "Design initiatives: New Taipei City Museum of art," Designboom (blog) September 10, 2011, accessed February 18, 2017, http://www.designboom.com/architecture/design-initiatives-new-taipei-city-museum-of-art/.
} 
the sky." 12 This full embeddedness into the natural environment and infrastructural network of the city with its parklands and streets suggests a new notion of the museum as urban field (see fig. 4). Besides being designed as the new landmark of New Taipei City in the literal sense of "marking the land" on the site of undeveloped nature area, the museum is featured as a landscape, thus turning city architecture into iconic geo-topography.

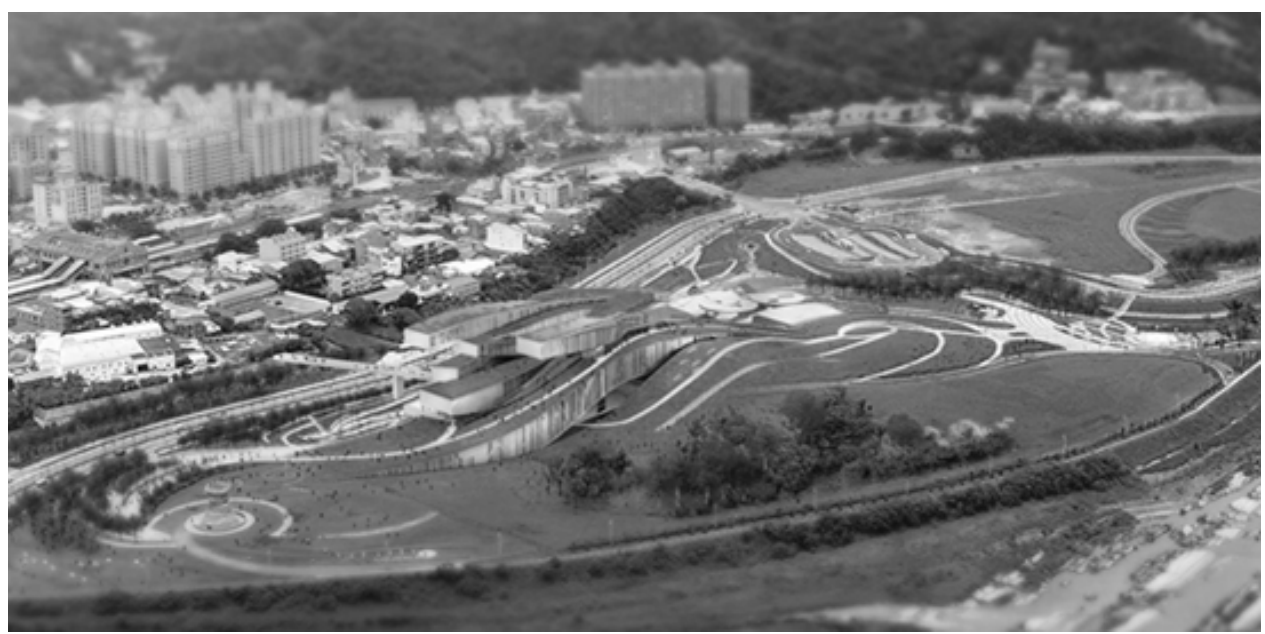

Fig. 4. Atelier Boronski \& Jean-Loup Baldacci, Urbanscape View of the New Taipei City Museum of Art. Source: Atelier Boronski.

The result of this landscaping of the museum on the island between the river crossroads is the museum's loss of its architectonic quality as a built entity and singular object of construction. The museum building dissolves into "a field of overlapping volumes, surfaces that form compressing and expanding interior and exteriuponor spaces, a quasi-urban 'field' to wander on."13 According to the design team, the museum is conceived as "a stream of consciousness" to dive into, and not as a building block." ${ }^{14}$ Does this concept suggest a disappearance of iconic signature architecture? Of a certain architectural disinterest in the visual representational power of centralized, enclosed building structures? Of the museum as walled fortress and protected sanctuary? In Boronski's and Baldacci's conceptual design for the New Taipei City Museum of Art, the flow

${ }^{12}$ Cit. following Alison Furuto, "New Taipei City Museum of Art Proposal/Jean-Loup BALDACCI \& Atelier BORONSKI," Archdaliy.com, October 26, 2011, accessed February 18, 2017, http://www.archdaily.com/178623/new-taipei-city-museum-of-art-proposal-jean-loup-baldacciatelier-boronski.

${ }^{13}$ Ibidem.

${ }^{14}$ Ibidem. 
of ideas is merged with the streams of landscape. The museum "sweeps up out of the ground in a dis-array of fluid elements, curving and crossing like the waters of the converging Yingge \& Dan rivers below." ${ }^{25}$ By interlacing park spaces and museum spaces, architecture and nature are fused. The construction is fluid and porous, with various openings and glazed apertures. This non-solidity not only reflects the stream-built landscape on the museum site, but also the porosity of the city feature of New Taipei.

The concept of the porous city was first developed with regard to Grand Paris. In 2009, it was adopted by the urban researcher Kuanchung Huang ${ }^{16}$ in order to describe the urban development form of Grand Taipei, the city-region around Taipei, as a space of flows through voids. The voiding out of volumes, implemented in the museum design of the New Taipei City Museum of Art by the inclusion of porous spaces and the integration of flat interlacing fields redefines the museum as an 'uncontained' museum, a non-object and non-site, a conceptual field for fantastic imagination where thoughts and feelings can flow unboundedly. Only on the basis of this non-objectiveness and fluidity, the everchanging phenomenon of art and city life intermingling can be given a museum fac(ad)e. The open and porous construction design embodies the mission of the New Taipei City Museum of Art to stay (con)temporary, that is to keep pace with the constant transformations and renewals in art, urban culture and society.

The organic fusion of the contemporary museum design with the features of a combined land- and cityscape is also found in the second winning design proposal by the Japanese practice Kengo Kuma + Associates (see fig. 5), yet with a different purpose and focus. In their design concept, the museum building grows out of the riverbank park like a ripened tropical fruit that pushes its way skywards from the ground. Some architecture critics have described the museum shape as a "giant green-skirted banana." ${ }^{17}$ Due to its growth-feature, the organic museum-shape competes with and ironically comments on the capitalist tower architecture as a main characteristic of global cityscapes. The double skin of the wavy steel-meshed building is symbolic of the double-bind function of the museum designed as both a cultural city hub and a green city cell. Infrastructurally,

\footnotetext{
${ }^{15}$ Comment by the architects Baldacci and Boronski, quotation following "Museum Taiwan. Winning Proposal of Taipei City Museum of Art," Archiscene, October 28, 2011, accessed February 18, 2017, http://www.archiscene.net/museum/winning-taipei-museum-art/.

${ }^{16}$ Kuanchung Huang, "Grand Taipei: The Porous City. A Research on the Urban Form of a Postcolonial City," The $4^{\text {th }}$ International Conference of the International Forum on Urbanism (IFoU), Amsterdam/Delft, 2009, paper online accessed February 18, 2017, http:/www.ifou.org/conf erences/2009delft/proceedings/5\%20The $\% 20$ Transformation $\% 20$ of $\% 20$ Urban $\% 20$ Form $/$ full $\% 20 \mathrm{p}$ apers/D023_Huang_K_Grand\%20Taipei\%20the\%20porous\%20city.pdf

${ }^{17}$ Tafline Laylin, "The Green Cell: Kengo Kuma's Design for the Taipei City Museum of Art Has an Insulating Green Roof," Inhabitat.com, October 19, 2011 accessed February 18, 2017, http://inhabitat.com/kengo-kuma\%E2\%80\%99s-taipei-city-museum-of-art-design-looks-likea-giant-green-skirted-banana/.
} 
the main hall of the museum, purposed to serve as a communication hub where workshops and gatherings take place and public and private life merge, connects with the nearby Yingge train station, a cable car and the riverbank trail. The mixed-used conception of the museum as a cultural, commercial and leisure hub finds its expression in the incorporation of retail facilities, park pavilions, and a flexible event program. The singular, monolithic institution of the contemporary art museum melts into a museum city park built on self-sustainability. Based on the principle of the green cell, the New Taipei City Museum of Art is transformed into an eco museum. The steel mesh which shapes the organic structure of the museum is capped with a mix of different cells, a combination of ETFE ${ }^{18}$ cushions, solar cells, ventilation louvers and green roof cells with LED screens. Equipped with this cellular form of highly sophisticated bio-technology, the museum can easily switch between art museum and eco museum. The breathable double-skin enables to incorporate the surrounding energy and nature environment, and to exteriorize the inner life of the museum and the nature of art.

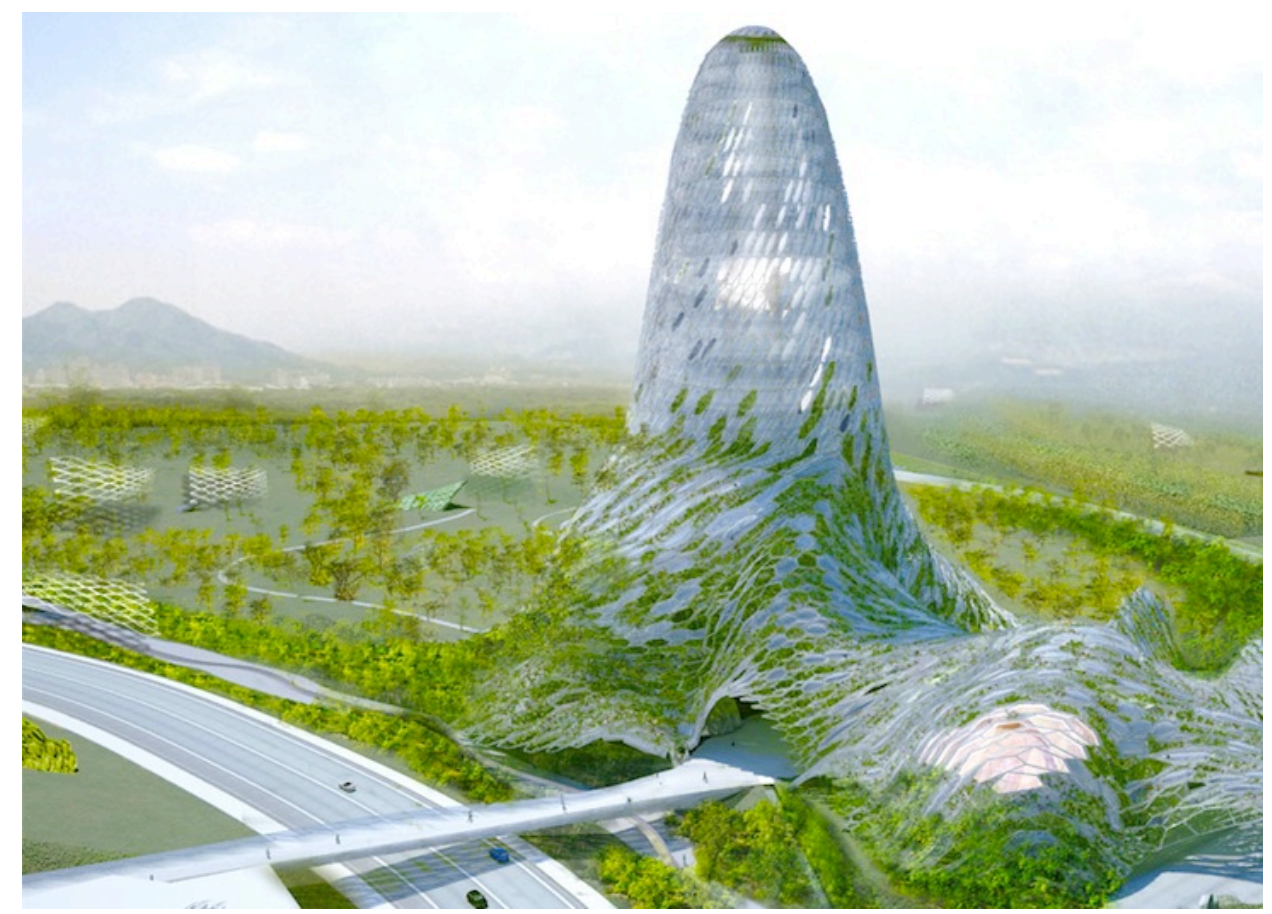

Fig. 5. Museum Design of the Practice Kengo Kuma \& Associates for the New Taipei City Museum of Art, International Design Competition 2011. Source: Kengo Kuma \& Associates.

\footnotetext{
${ }^{18}$ ETFE is a fluorine-based plastic substance with excellent chemical, electrical and high energy radiation resistance properties.
} 
The microstructural element of the architectural design, the energy-saving and environmentally-friendly green cell is scaled up to a macrostructural urban cell - the green museum city. By the imprint of innovative eco architecture, the contemporary art museum is morphed into an urban Green Museum. The third winning proposal by the Spanish architect Federico Soriano Pelaez has taken a completely different approach (see fig. 6).

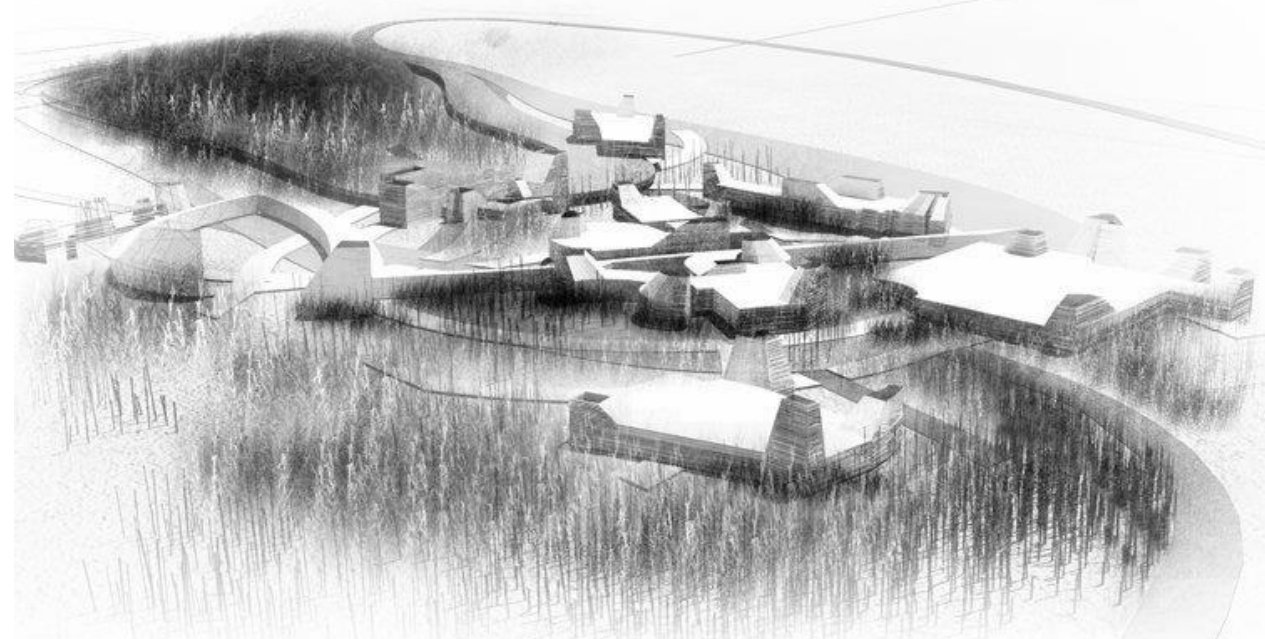

Fig. 6. Aerial View of the Museum Design of Federico Soriano Pelaez for the New Taipei City Museum of Art, International Design Competition 2011. Source: Estudio Federico Soriano Pelaez.

The design aims at a global hypermuseum which contains "the entirety of all the museums in the world." 19 This supermuseum is configured by a recollection of generic fragments from the plans of the most important hundred art museums around the world. In that sense, it represents "architecture as a refined abstraction of a historic landscape" 20 and a meta-postmodern museum dedicated to the idea of postproduction (see fig. 7). The recollective design assemblage challenges many firmly entrenched museum conceptions. Firstly, it questions the need for a new museum: "Do you want just another project? Do you want just another form? A form which evokes many others. Just one more among the uncountable collection of forms generated in recent years?"21 Secondly, it queries the innovativeness, creativity and originality of the architectural design. Thirdly, it doubts the value of the museum as a built material object. Related to

\footnotetext{
${ }^{19}$ Furuto, "New Taipei City."

${ }^{20}$ Ibidem.

${ }^{21}$ Ibidem.
} 
this, it challenges the singularity of the museum. Conceived as a museum containing all other museums, it takes shape as world museum city. Fourthly, it undermines the design concept of the contemporary by means of the relativizing argument that "everything can be read as current architecture if we take a contemporary perspective on it." ${ }^{, 2}$ Form doesn't follow function any more. Any function can fit into any form. "A reflection on what we think of history or on the idea of exhibiting" 23 is the most important feature of the museum design. The architectonic redefinition of the museum follows the idea of the conceptual art work. This cognitive turn reinforces the effect of an imagined, surreal (or even hyperreal) museum transmitting the past to the future.

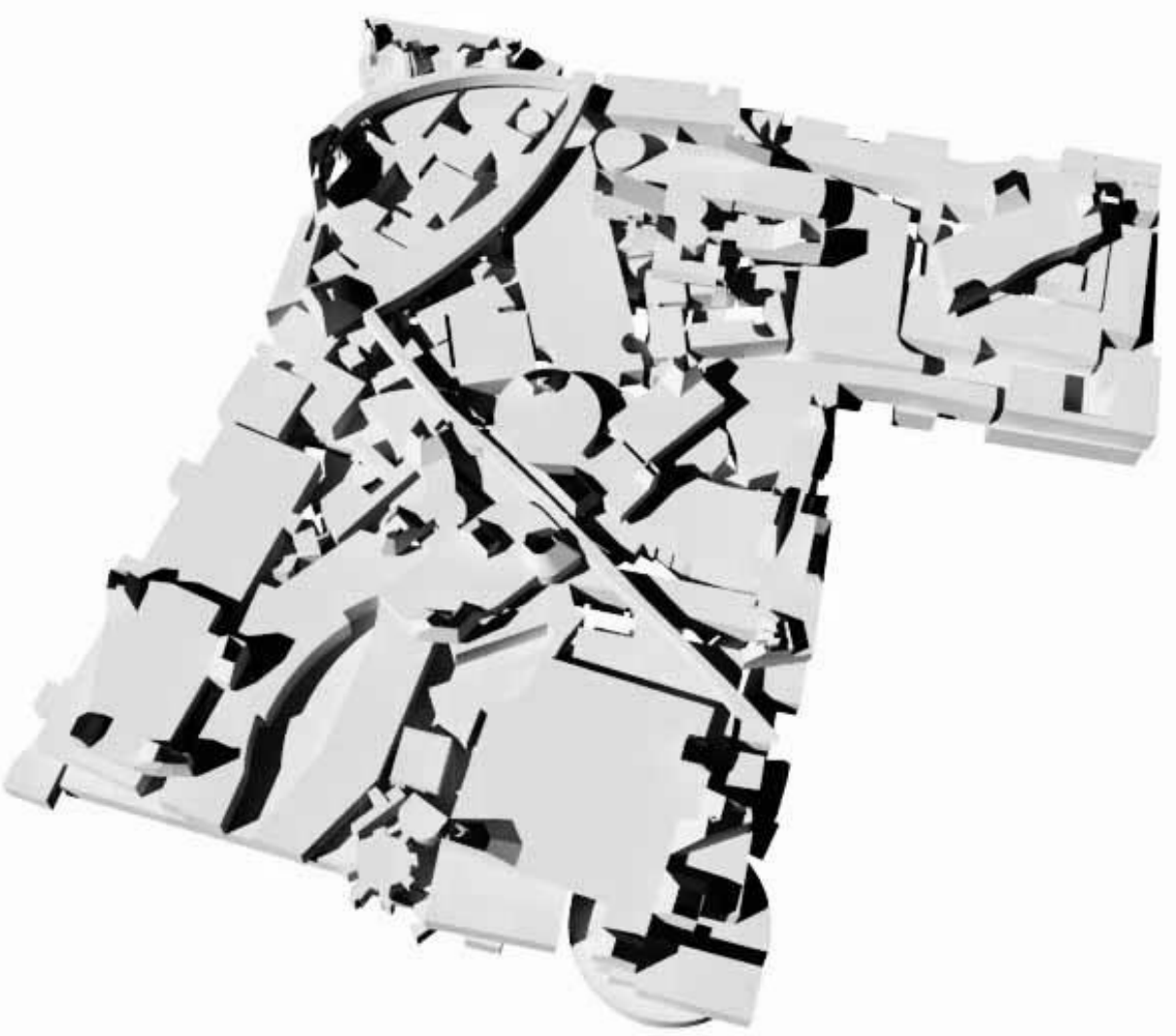

Fig. 7. Composition of Volumes, Museum of All Museums, Design of Federico Soriano Pelaez, 2017. Source: Estudio Federico Soriano Pelaez.

\footnotetext{
22 Ibidem.

${ }^{23}$ Ibidem.
} 


\section{THE EMERGENCE OF A NEW TYPE OF CITY MUSEUM OF CONTEMPORARY ART}

The urban design study on the New Taipei City Museum of Art in Taiwan could illustrate how deeply the design of this new museum of contemporary art is embedded into urban masterplanning as a method of strategic global city-region development. Although this strategic trend of urban-embedded museum design appears to be a rather worldwide tendency, symptomatic of the global city contest for cultural, social, and economic capital, it can also be identified as a dominant and distinctive contemporary phenomenon and feature in rising Asian cities. Given that Asian countries register the highest rates of city development and urbanization in the world and therefore have to define and implement new urban planning strategies in order to build sustainable cities and enhance the quality of city life, the tight connection between urban design and cultural planning (including museum design) is a logical and natural consequence of this large-scale planning process.

The most important urban turn in contemporary museum design, stimulated by the rise of and competition between global cities, is its reorientation towards the future. First and foremost, the New Taipei City Museum of Art in Taiwan is conceived as a showroom to the future, a dream space rather than a documentary space for the recollection, remembrance and retention of the past. Due to this change of direction, the contemporary museum (type) transmutes into a temporary, transient museum. This transformation, the impact of the imagined future onto the presence of the built physicality, is reflected in the architectural design proposals for the museum. The substance of the museum immaterializes under the pressure of newness and the condition of temporariness as a symptom of the acceleration of urban life. The museum as a physical object dissolves into a non-object. It is opened into a porous or fluid space that allows the interior to become continuous with the exterior of the urban field and environment. The new art museum in New Tapei City is no longer conceived as a stand-alone monument and architectonic city landmark of centralized art power, but as a network node that directly connects with the urban life of the city and its full range of activities. It is designed to build neighborhoods, networks and communities with other museums, cultural heritage sites and institutions in the urban area where it is located. The city location and urban site have emerged as primary defining elements for the museum construction. In this regard, the city performs and perforates the museum, molding it into a veritable city museum of art. 


\section{BIBLIOGRAPHY}

Appadurai, Arjun. "Disjuncture and Difference in the Global Cultural Economy." Public Culture, 2, no. 2 (199): 1-24.

Baldacci, Jean-Loupand and Boronski Peter. "Museum Taiwan. Winning Proposal of Taipei City Museum of Art." Archiscene, October 28, 2011, accessed February 18, 2017, http://www.archiscene.net/museum/winning-taipei-museum-art/.

Furuto, Alison. "New Taipei City Museum of Art Proposal/Jean-Loup BALDACCI \& Atelier BORONSKI." Archdaliy.com, October 26, 2011, http://www.archdaily.com/178623/newtaipei-city-museum-of-art-proposal-jean-loup-baldacci-atelier-boronski.

Grieco, Lauren. "Design initiatives: New Taipei City Museum of art." Designboom (blog) September 10, 2011, online http://www.designboom.com/architecture/design-initiatives-newtaipei-city-museum-of-art/.

Huang, Kuanchung."Grand Taipei: The Porous City. A Research on the Urban Form of a Postcolonial City." The $4^{\text {th }}$ International Conference of the International Forum on Urbanism (IFoU), Amsterdam/Delft, 2009, online http://newurbanquestion.ifou.org/proceedings $/ 5 \%$ 20The\%20Transformation\%20of\%20Urban\%20Form/full\%20papers/D023_Huang_K_Grand \%20Taipei\%20the\%20porous\%20city.pdf.

Kim, Won-Bae. "Strategic Approaches for Sustainable Cultural Development in Asian Cities." Paper presented at the International Conference on the Culture and Economy of Cities, jointly organized by the Korea Research Institute for Human Settlements and the University of New South Wales, Seoul, Korea, 11-12 October 2001, online http://newurbanquestion.ifou.org/ proceedings $/ 5 \% 20$ The $\% 20$ Transformation $\% 20$ of $\% 20$ Urban $\% 20$ Form/full $\% 20$ papers/D023 Kim_W_Grand\%20Taipei\%20the\%20porous\%20city.pdf.

Kong, Lily. "Cultural Icons and Urban Development in Asia: Economic Imperative, National Identity, and Global City Status." Political Geography 26 (2007): 383-404.

Laylin, Tafline. "The Green Cell: Kengo Kuma's Design for the Taipei City Museum of Art Has an Insulating Green Roof." Inhabitat.com, October 19, 2011, http://inhabitat.com/kengokuma\%E2\%80\%99s-taipei-city-museum-of-art-design-looks-like-a-giant-green-skirtedbanana/.

Message, Kylie. New Museums and the Making of Culture. Oxford: Berg, 2010.

"New Taipei City Museum of Art Conceptual Design International Competition," accessed February 18, 2017, http://akichiatlas.com/en/archives/new_taipei_museum.php. 